\title{
Ileal and faecal digestibility of Jerusalem artichokes (Helianthus tuberosus L.) in pigs
}

\author{
J. Ly, M. Macias, J.L. Reyes and Vilda Figueroa
}

\author{
Swine Research Institute \\ P.O. Box 1, Punta Brava \\ La Habana, Cuba
}

(Received 10 May 1995; accepted 22 August 1995)

\begin{abstract}
Ileal and faecal digestibility of nutrients was studied on 8 intact and 4 ileorectostomized $45 \mathrm{~kg}$ pigs assigned at random according to a replicated $2 \times 2$ Latin square design to one of two diets containing either refined sucrose or Jerusalem artichoke tubers (fresh, whole) as the only source of energy. The dicts were formulated with soyabean meal to be isonitrogenous. Ileal organic mather (OM) digestibility of Jerusalem artichoke diet was significantly lower $(P<0.001)$ than of the sucrose diet (48.5 vs $89.1 \%$, respectively). This phenomenon was less pronounced $(\mathrm{P}<0.05)$ in faecal $\mathrm{OM}$ digestibility in both sources of energy $(86.0 \mathrm{vs} 95.2 \%$, respectively) indicating decisive participation of the large intestine in the digestion of nutrients of Jerusalem artichoke tubers. The sucrose diet led to higher and lower SCFA concentrations in the ileal and faecal sites ( 117.5 and $41.3 \mathrm{mmol} / 100 \mathrm{~g} \mathrm{DM})$, while the reverse occurred with the Jerusalem artichoke tubers $(21.0$ and $117.8 \mathrm{mmol} / 100 \mathrm{~g} \mathrm{IMM})$. There was a certain dictary influence in the lactate level in the precaecal part of the alimentary tract of the animals. The experimental data indicate a different site of digestion for both sources of fructose studied and, at the same time, a different extent of digestion of nutrients by the pig.
\end{abstract}

KEY WORDS: pigs, Jerusalem artichoke, sucrose, digestibility, fermentation

\section{INTRODUCTION}

Jerusalem artichoke (Helianthus tuberosus L.) is a high yielding, perennial crop which can be used either for industrial purposes (Baker et al., 1990) or for outdoor pig production in pastoral systems (Cañas, 1990; Jost, 1992). In this connection, although Jerusalem artichoke is usually provided to pigs having access to other feeds, there are few studies concerning the energy value of the tubers, which has been suggested to be rather low (Fingerling, 1994, cited by Sereni, 1981). This aspect is very important if considered that inulin is the main 
carbohydrate constituent of the feed. Since inulin is a polyfructan that cannot be well digested by the pig (Graham and Åman, 1986) a decrease in energy available to animals should be expected. In this sense, microbial digestion might play a very important role in the hind gut of the pig.

The objective of the present study was to compare the apparent ileal and faecal digestibilites of nutrients in pigs' diets containing Jerusalem artichoke. In order to evaluate microbial participation in diet utilization, some fermentation indices were also determined in the digesta and faeces.

\section{MATERIAL AND METHODS}

Two experiments were conducted to determine nutrients digestibility of Jerusalem artichoke in the pig.

\section{Experiment 1.}

Four Landrace $x$ Yorkshire $x$ Duroc barrows weighing on average $40 \mathrm{~kg}$ were surgically prepared with an end-to-end ileo-rectal anastomosis using the method described by Green et al. (1987). The pigs were individually kept in conventional metabolic cages and alloved to recover after surgery for 3 weeks before the test diets were given. The test diets contained $15 \%$ crude protein with Jerusalem artichokes or sucrose as the only energy source in the diet. Whole Jerusalem artichoke tubers were harvested in Cuba and frozen immediately until utilization in the digestion trials. The DM of the tubers was $228.5 \mathrm{~g} / \mathrm{kg}$. Diet composition is shown in Table 1.

After 3-weeks of recovery from surgery, the pigs were allocated to either of the two diets in a $2 \times 2$ Latin square design. The level of feed intake was $0.08 \mathrm{~kg}$ $\mathrm{DM} / \mathrm{kg} \mathrm{W}^{0.75}$ in two equal meals at 9.00 and 15.00 for a 7 -day adaptation period before collections were made. The sucrose-based diet was given mixed to the pigs. In the case of the Jerusalem artichoke diet, soyabean meal was mixed with minerals and vitamins and then offered to the animals. This procedure assured complete consumption of the dry components of the ration. Afterwards, the intact tubers were given to the pigs. Water was freely available to the animals during the experiment.

Ileal digesta was collected every hour for 2 days and pooled by weight so as to give two daily ileal samples per pig per diet. These two daily samples were analyzed separately and the data was pooled to give one digesta sample per pig per treatment. All samples were frozen immediately after collection. The $\mathrm{pH}$ value was measured potentiometrically in fresh digesta. Dry matter and nitrogen contents in feed and in the pooled samples were estimated by drying at $105^{\circ} \mathrm{C}$ in 
TABLE 1

Composition of the diets

\begin{tabular}{|c|c|c|c|}
\hline & \multicolumn{3}{|c|}{ Diets } \\
\hline & Sucrose & & $\begin{array}{l}\text { Jerusalem artichoke } \\
\text { tubers }\end{array}$ \\
\hline \multicolumn{4}{|l|}{ Ingredients, $\mathrm{g} / \mathrm{kg}$} \\
\hline soyabean oilmeal & 324 & $i$ & 170 \\
\hline refined sucrose & 629 & & - \\
\hline Jerusalem artichoke tubers & - & & 775 \\
\hline $\mathrm{CaHPO}_{4} \cdot 2 \mathrm{H}_{2} \mathrm{O}$ & 26 & & 26 \\
\hline $\mathrm{NaCl}$ & 8 & & 8 \\
\hline vitamins and trace elements ${ }^{1}$ & 13 & & 13 \\
\hline \multicolumn{4}{|l|}{ Chemical composition, $\mathrm{g} / \mathrm{kg}$} \\
\hline dry matter & 951.1 & & 281.9 \\
\hline \multicolumn{4}{|l|}{ In dry matter: } \\
\hline ash & 56.2 & & 89.6 \\
\hline organic matter & 943.8 & & 910.4 \\
\hline crude protein & 150.0 & & 149.5 \\
\hline crude fibre & 36.6 & & 103.4 \\
\hline Energy, $\mathrm{kJ} / 10 \mathrm{~g} \mathrm{DM}$ & 161.4 & & 167.7 \\
\hline
\end{tabular}

' supplied per kg diet:

1600 I.U. A, 160 I.U. $\mathrm{D}_{3}, 2 \mathrm{mg}$ thiamine, $3 \mathrm{mg}$ riboflavine, $300 \mathrm{mg}$ choline, $15 \mathrm{mg}$ niacin, $5 \mathrm{mg}$ pantothenic acid, $15 \mathrm{mg}$ pyridoxinc, $0.5 \mathrm{mg}$ folic acid, $25 \mu \mathrm{g}$ cyanocobalamin, $10 \mathrm{mg}$ tocopheryl acetate, $2 \mathrm{mg}$ vitamin $\mathrm{K}, 10 \mathrm{mg} \mathrm{Cu}, 40 \mathrm{mg} \mathrm{Fe}, 0.5 \mathrm{mg} \mathrm{I}, 0.4 \mathrm{mg} \mathrm{Co}$

an air-forced oven and by the Kjeldahl procedure, respectively. Crude fibre was determined according to AOAC (1990), whereas the calorific value was measured in an adiabatic bomb calorimeter in previously dried aliquots of intestinal content. A sample of fresh ileal digesta was suspended in deionized water $1: 3$ by weight and centrifuged for $15 \mathrm{~min}$ at $5000 \mathrm{rpm}$ and portions of the supernatant were taken for total SCFA determination by steam distillation as outlined by Ly (1990) and for ammonia estimation by microdiffusion (Conway, 1962). Another aliquot was deproteinized with equal proportions of $5 \% \mathrm{ZnSO}_{4}$ and $0.3 \mathrm{~N} \mathrm{Ba}(\mathrm{OH})_{2}$, and lactic acid was determined by the Barker and Summerson (1941) technique.

\section{Experiment 2.}

Eight barrows weighing approximately $45 \mathrm{~kg}$ were randomly assigned to the same diets as in Experiment 1 according to a $2 \times 2$ Latin square design. The pigs were individually penned and fed their respective diets twice daily with the same routine as in the previously described Experiment 1 for one week before being 
transferred to the metabolic cages. During the next week the 5-day collection period followed 2 days adjustment of the animals to the cages. Faeces were collected from each pig every morning and stored frozen.

Daily samples were later pooled to obtain one faecal sample per animal per treatment. Urine was collected into polyethylene bottles containing $40 \mathrm{ml}$ of $5 \%$ sulphuric acid and sampled every day. The samples were kept frozen and then thawed and analyzed directly nitrogen. The energy content of dry urine was determined in an adiabatic bomb calorimetr by a modification of the method described by Nijkamp (1965). The samples of pig urine were freeze-dried in polyethylene sheets over Petri dishes. Other analyses in feed and faeces were carried out as described in Experiment 1.

\section{Statistical analysis}

Data were subjected to analyses of variance to test for significant differences between treatment means. Duncan's (1955) multiple range test was used when the analysis of variance was significant between means. Regression analyses were carried out in the required cases.

\section{RESULTS}

There was no difficulty in introducing the pigs to the diet containing Jerusalem artichoke tubers. However, the animals exhibited the characteristic pattern of feed intake already described (Ly et al., 1994), i. e. eating throughout a considerable period of time. In contrast, the sucrose-based diet was rapidly consumed by the pigs. No feed refusals were observed during either experiment.

Daily ileal and faecal flows of either fresh digesta or faeces were significantly $(\mathrm{P}<0.001)$ lower after feeding the sucrose than Jerusalem artichokes diet caused a higher DM concentration in ileal digesta than the sucrose diet $(P<0.05)$, but the reverse was evident in faeces $(\mathrm{P}<0.001)$. In fact, $\mathrm{DM}$ concentration in faeces from pigs fed on sucrorse was doubles that of the animals consuming the Jerusalem artichokes. Daily ileal flow of water induced by sucrose was nearly one third that occurring in pigs fed the tubers. A considerable reduction in daily flow of fresh content and water between the ileal and rectal sites respectively was found, although it was not as remarkable in the Jerusalem artichoke-based diet.

It was observed that the sucrose-based diet exhibited high digestibility values for all nutrients and energy with the exception of the crude fibre fraction (Table 3 ). In contrast, the pigs fed the Jerusalem artichokes digested small amounts of the diet in the precaecal sections of the digestive tract. Therefore, a highly significant difference was found between both treatments $(P<0.001)$ in ileal 
TABLE 2

Ileal and faecal flow of fresh content and water

\begin{tabular}{|c|c|c|c|}
\hline & \multicolumn{2}{|c|}{ Diets } & \multirow[b]{2}{*}{ SE } \\
\hline & Sucrose & $\begin{array}{c}\text { Jerusalem artichoke } \\
\text { lubers }\end{array}$ & \\
\hline \multicolumn{4}{|l|}{ Experiment 1} \\
\hline \multicolumn{4}{|c|}{ Ileal flow, g/day per $\mathrm{kg}$ DM intake } \\
\hline fresh digesta & 1504 & 5395 & $729 * * *$ \\
\hline water & 1400 & 4900 & $675^{* * *}$ \\
\hline ileal DM, g/100 g & 7.02 & 9.14 & $0.53^{*}$ \\
\hline \multicolumn{4}{|l|}{ Experiment 2} \\
\hline \multicolumn{4}{|c|}{ Faecal flow, g/day per kg DM intake } \\
\hline fresh faeces & 182 & 964 & $281 * * *$ \\
\hline water & 108 & 812 & $243 * * *$ \\
\hline faecal DM, g/100 g & 33.70 & 14.54 & $1.21 * * *$ \\
\hline
\end{tabular}

TABLE 3

Ileal and faecal digestibility of nutrients and energy

Dicts

$\begin{array}{ccc}\text { Sucrose } & \begin{array}{c}\text { Jerusalem artichoke } \\ \text { tubers }\end{array} & \text { SE }\end{array}$

\begin{tabular}{lrrl}
\hline leal digestibility, g/kg & & \\
dry matter & 885 & 465 & $15^{* * *}$ \\
ash & 488 & 385 & $12^{* * *}$ \\
organic matter & 891 & 485 & $14^{* * *}$ \\
nitrogen & 850 & 475 & $14^{* * *}$ \\
crude fibre & 23 & 69 & $10^{* * *}$ \\
energy & 904 & 489 & $17^{* * *}$ \\
& & & \\
Faecal digestibility, g/kg & & & $19^{* *}$ \\
dry matter & 933 & 859 & 63 \\
ash & 619 & 706 & $15^{* *}$ \\
organic matter & 952 & 860 & $27^{* * *}$ \\
nitrogen & 870 & 682 & $42^{* *}$ \\
crude fibre & 770 & 665 & $19^{*}$ \\
energy & 941 & 864 & \\
\hline
\end{tabular}

** $\mathrm{P} \leqslant 0.01 ; * * * \mathrm{P} \leqslant 0.001$ 
digestibility of all the nutrients studied and energy. This dissimilarity was less pronounced in faecal digestibility of DM, OM and energy in favour of the sucrose diet $(\mathrm{P}<0.01)$. However, an extreme difference between both treatments was observed for faecal digestibility of $\mathrm{N}(\mathrm{P}<0.001)$ whereas ash digestibility was not affected by treatments $(P>0.10)$.

Both ileal and total energy digestibility $(\mathrm{Y}, \%)$ correlated $(\mathrm{P}<0.001)$ with $\mathrm{OM}$ digestibility $(\mathrm{X}, \%)$ according to respective regression equations:

$$
\begin{aligned}
& \mathrm{Y}=0.187+1.013 \mathrm{X} \pm 0.037, \mathrm{r}=0.996 \\
& \mathrm{Y}=-5.608+1.051 \mathrm{X} \pm 0.057, \mathrm{r}=0.980
\end{aligned}
$$

Nutrients and energy disappearance in the large intestine is presented in Table 4. The crude fibre fraction disappeared to a great extent in the large intestine of pigs fed both diets. On the other hand, the sucrose-based diet caused a rather small contribution of the large intestine to the overall digestion of the diet (only $5.1 \%$ ). The reverse was observed when the Jerusalem artichokes were included in the diet, since some $45.9 \%$ of the DM was digested in that section of the digestive tract.

Both diets caused equal concentrations of SCFA in ileal digesta, although a trend was found $(\mathrm{P}<0.10)$ for Jerusalem artichokes to induce higher ileal concentrations of these metabolites. Accordingly, pigs fed the tubers had a significanty $(\mathrm{P}<0.01)$ higher concentrations of lactic acid in the ileum than those fed the sucrose based diets. Ammonia concentration in ileal digesta was very high in the animals fed the diet containing Jerusalem artichokes $(\mathrm{P}<0.05)$ as compared with the sucrose treatment. There was no dietary influence on $\mathrm{pH}$ values, although the highest values were always encountered in ileal digesta of pigs fed the Jerusalem artichoke diet. Daily flow of SCFA was independent of the source of dietary energy. However, daily ileal flow of lactic acid $(\mathrm{P}<0.01)$ and

TABLE 4

Contribution of the large intestine in digestion of diets

\begin{tabular}{lccccc}
\hline & \multicolumn{2}{c}{ Digestibility, g/kg } & & \multicolumn{2}{c}{$\begin{array}{c}\text { Contribution to overall } \\
\text { digestion, \% }\end{array}$} \\
\cline { 2 - 3 } \cline { 5 - 6 } \cline { 5 - 6 } & Sucrose & $\begin{array}{c}\text { Jerusalem } \\
\text { artichoke tubers }\end{array}$ & & Sucrose & $\begin{array}{c}\text { Jerusalem } \\
\text { artichoke tubers }\end{array}$ \\
\hline Dry matter & 48 & 394 & 5.1 & 45.9 \\
Ash & 123 & 321 & & 19.9 & 45.5 \\
Organic matter & 61 & 375 & & 6.4 & 43.6 \\
Nitrogen & 20 & 207 & & 2.3 & 30.4 \\
Crude fibre & 747 & 596 & & 97.0 & 89.6 \\
Energy & $37^{2}$ & 375 & 3.9 & 43.4 \\
\hline
\end{tabular}

' represents faecal minus ileal digestibility

${ }^{2}$ cxpressed in $\mathrm{kJ} / \mathrm{MJ}$ 
ammonia $(\mathbf{P}<0.05)$ was much greater in animals fed Jerusalem artichokes than the sucrose diet.

Faecal concentration of SCFA was high in the animals fed the Jerusalem artichokes and significantly different $(P<0.001)$ from those fed the sucrose diet. Faecal $\mathrm{NH}_{3}$ concentration exibited the same characteristics $(\mathrm{P}<0.05)$ between treatments. Faecal $\mathrm{pH}$ values showed little variability among the animals from the same treatment, lower values corresponding $(\mathrm{P}<0.05)$ to pigs fed Jerusalem artichokes. Daily faecal flows of SCFA $(P \leqslant 0.001)$ and $\mathrm{NH}_{3}(P \leqslant 0.05)$ were consistently higher in the animals fed Jerusalem artichokes in comparison to those eating the sucrose diet.

A significant $(\mathrm{P}<0.001)$, negative correlation $(\mathrm{r}=-0.992)$ was found between daily faecal excretion of SCFA and faecal OM digestibility. This relationship was not significant in the ileum $(r=-0.363)$. It was observed, however, that daily ileal flow of lactic acid was inversely correlated with ileal OM digestibility $(r=-0.893$; $\mathrm{P}<0.01$ ). In both sampling sites the daily flow of $\mathrm{NH}_{3}$ was negatively correlated

TABLE 5

Ileal and faccal indices of fermentation in pigs

\begin{tabular}{|c|c|c|c|}
\hline & \multicolumn{2}{|c|}{ Dicts } & \multirow[b]{2}{*}{$\mathrm{SE}$} \\
\hline & Sucrose & $\begin{array}{c}\text { Jerusalem artichoke } \\
\text { tubers }\end{array}$ & \\
\hline \multicolumn{4}{|l|}{ Experiment 1} \\
\hline \multicolumn{4}{|c|}{ Ileal concentration, $\mathrm{mmol} / 100 \mathrm{~g}$ DM } \\
\hline SCFA & 147.73 & 104.85 & $12.66^{*}$ \\
\hline lactic acid & 10.69 & 30.07 & $2.67^{* *}$ \\
\hline $\mathrm{NH}_{3}$ & 9.44 & 84.82 & $15.58 * *$ \\
\hline Ileal pH & 5.60 & 6.25 & 0.33 \\
\hline \multicolumn{4}{|c|}{ Daily ilcal flow, $\mathrm{mmmol} / \mathrm{kg}$ DM intake } \\
\hline SCFA & 137.77 & 137.89 & 17.51 \\
\hline lactic acid & 10.04 & 39.35 & $3.50^{* *}$ \\
\hline $\mathrm{NH}_{3}$ & 8.30 & 109.39 & $18.12^{* *}$ \\
\hline \multicolumn{4}{|l|}{ Experiment 2} \\
\hline \multicolumn{4}{|c|}{ Faecal concentration, mmol/100g DM } \\
\hline SCFA & 27.14 & 130.68 & $11.92^{* * *}$ \\
\hline $\mathrm{NH}_{3}$ & 15.35 & 38.83 & $3.76^{* *}$ \\
\hline Faecal pH & 5.87 & 5.47 & $0.08^{* *}$ \\
\hline \multicolumn{4}{|c|}{ Daily faecal flow, mmol/kg DM intake } \\
\hline SCFA & 28.32 & 157.32 & $17.77^{* * *}$ \\
\hline $\mathrm{NH}_{3}$ & 15.10 & 46.86 & $5.56^{* *}$ \\
\hline
\end{tabular}

* $\mathrm{P} \leqslant 0.10 ;{ }^{* *} \mathrm{P} \leqslant 0.01 ; * * * \mathrm{P} \leqslant 0.001$ 
to OM digestibility: at the ileum the $\mathrm{r}$ value was $-0.913(\mathrm{P}<0.001)$, whereas at the rectum the corresponding $r$ value was $-0.807(\mathbf{P}<0.001)$.

\section{DISCUSSION}

According to data reported by Ly (1992), some $1570 \mathrm{~g}$ of fresh digesta pass daily through the terminal ileum and $157 \mathrm{~g}$ of faeces is voided daily in pigs per kilogram of a sucrose-based diet. In spite of differences inherent to each study, these figures do agree fairly well with those reported in the present paper. On the other hand, the values encountered for daily ileal and faecal flow of materials in these experiments perhaps could be representative of two very dissimilar types of fructose containing diets. In fact, a very digestible diet such as that based on sucrose as the predominat carbohydrate can determine a very scarce amount of ingesta residues arriving to the terminal ileum, and as a consequence, the same even more pronounced, phenomenon must occur at the rectum.

In contrast with high digestibility of the diet and a concomitant low daily flow of ileal and faecal materials, as determined by sucrose, the reverse was evident in the pigs fed the Jerusalem artichoke tubers. The very low ileal digestibility of a diet containing fresh tubers of Jerusalem artichokes as the main source of carbohydrate is supported by the findings of Graham and Åman (1986) who claimed for the pig a $40 \%$ ileal digestibility of minced, freeze dried tubers. On the other hand, since the early works of Cunningham et al. (1963), it is well known that low ileal digestibility of a diet is accompanied by relatively high amounts of digesta passage to the caecum and colon. This occurs in cases where some carbohydrates such as whey (Ekstrom et at., 1975) or raw potatoes (Ledinek, 1970) can not be completely digested in the small intestine. Jerusalem artichokes can be another example. Interestingly, the experiment reported herein also provides more evidence that digesta enterning the large intestine in these circumstances does not differ greatly in DM concentration from that originated by an efficient digestive process.

Jerusalem artichoke tubers are very rich in fructan, a non-starch polysaccharide, in which fructose is linked by beta 2-1 linkages not hydrolized by endogenous enzymes of the pig, as has been emphasized by Farnworth (1993). Fructose can be liberated from fructans when subjected to acidic hydrolysis during the gastric stage of feed digestion. That possibility could be responsible for partial digestibility up to the ileum of Jerusalem artichokes, sine only $50 \%$ of the ingested fructans has been recovered in both the duodenal and ileal sections of the small intestine (Graham and Åman, 1986).

Precaecal disappearance of nutrients from Jerusalem artichoke or sucrose diets does not necessary imply absortion of fructose and other carbohydrate 
monomers as such. Judging by the presence at the ileum of common end-products of bacterial activity such as organic acids, it must be taken into consideration that some of the carbohydrates are subjected to microbial transformation in the fore gut. In this experiment it was observed that daily ileal SCFA flow was not inversely correlated with ileal OM digestibility which disagrees with the data of Jentsch et al. (1990), who observed such an invers correlation with daily faecal excretion of these acids.

In this connection it could be assumed that ileal flow of lactic acid could be more representative of precaecal OM disappearance, when the carbohydrate fraction of the diet is poorly digested and absorbed in the small intestine. On the other hand, similar interdependence between the daily ileal flow of ammonia and OM digestibility is yet to be understood.

Considerable low ileal $\mathrm{pH}$ has been observed in pigs fed either sucrose or Jerusalem artichoke, in contrast to what has been in this study (Ly, 1971; Braude et al., 1976). These finding might support the hypothesis that substantial bacterial activity could occur at least in the ileum of the pigs, if digesta $\mathrm{pH}$ is a good indicator of this status.

In contrast to digestion in the small intestine, more nutrients and energy disappeared in the caecum and colon of the pigs fed Jerusalem artichokes than the sucrose diet. Approximately $43.4 \%$ of the energy disappearing in the alimentary tract of the animals given Jerusalem artichokes was digested in the large intestine, while the corresponding value for the sucrose-based diet being only $3.9 \%$. These estimations do not agree with data summarized by Shi and Noblet (1993) who considered that the contribution of the large intestine to digestion of energy is rather stable and ranges from 15 to $20 \%$ of mouth-to-rectum energy digestibility.

It may be concluded from these studies that digestion of intact Jerusalem artichoke tubers in pigs is clearly dependent on microbial activity in the alimentary tract. Since absorption of end products of carbohydrate hydrolysis from Jerusalem artichokes will necessarily make more energy available to the animals than end products of bacterial activity, methods to improve the former need to be developed if biological harvest is not the strategy selected for pig production in Jerusalem artichoke feeding systems.

\section{REFERENCES}

AOAC., 1990. Official Methods of Analysis. 15th ed. Association of Official Analytical Chemits. Washington, DC

Baker L., Thomassin P.J., Henning J.C., 1990. The economic competitiveness of Jerusalem artichoke (Helianthus tuberosus) as an agricultural feedstock for ethanol production for transportation fuels. Can. J. Agric. Econ. 38, 981-990 
Barker S.B., Summerson W.H., 1941. The colorimetric determination of lactic acid in biological materiats. J. Biol. Chem. 138, 535-548

Braude R., Fulford R.J., Low A.G., 1976. Studies on digestion and absorption in the intestine of growing pigs. Measurements of the flow of digestion and pH. Brit. J. Nutr. 36, 497-510

Cańas R., 1990. Uso del topinambur (Helianthus tuberosus) y ensilaje de pescado en la producción porcina extensiva. In: Taller Reg. FAO. Utilizatión de Recursos Alimentarios cn la Producción Porcina de Aémrica Latina y el Caribe. La Habana, pp. 10

Conway E.J., 1962. Microdiffusion analysis and volumetric error. Crosby Lockwood and Son. Ltd Cunningham H.M., Friend D.W., Nicholson J.W.G., 1963. Observations on digestion in the pig using a re-entrant intestinal fistula. Can. J. Anim. Sci. 43, 215-225

Duncan D.B., 1955. Multiple range and multiple f tests. Biometric 11, 1-41

Ekstrom K.E., Benevenga N.J., Grummer R.H., 1975. Effect of dicts containing dried whey on the lactase activity of the small intestinal mucosa and the contents of the small intestine and caecum of the pig. J. Nutr. $105,851-860$

Farnworth E.R., 1993. Fructans in human and animal diets In: M. Suziki, N.J. Chatterton (Editors). Science and technology of fructans. CRC Press. Boca Raton, pp. 258-272

Graham H., Åman P., 1986. Composition and digestion in the pig gastrointestinal tract of Jerusalem artichoke tubers. Food Chem. 22, 67-76

Green S., Bertrand S.L., Duron M.J.C., Maillard R.A., 1987. Digestibility of amino acids in maize, wheat and barley meal, measured in pigs with ileo-rectal anastomosis and isolation of the large intestine. J. Sci. Food Agric. 41, 29-43

Jenstch W., Henning V., Wunsche J., Wittenburg H., Souffrant W.B.,1990. Methodological studies on the formation of $\mathrm{CO}_{2}$ and volatile fatty acids in porcine ileo-chyme and faeces. Arch. Anim. Nutr. 40, 1019-1026

Jost M., 1992. Paturage des porcs: topinambours et prairies artificielles. Rev. Suisse Agric. 24 (3), 173 Ledinck M., 1970. Untersuchungen über die Beteiligung von Mikroorganismen am Verdauungsstoffwechsel des Schweines bei Fütterung roher and gedampfter Kartoffeln. Thesis Dr. Med. Vet., Institut für Tierphysiologic, Universität München, München, pp.99

Ly J., 1971. Intestinal digestion of molasses in the growing pig. Cuban J. Agric. Sci. 5, 351-362

Ly J., 1990. Crude fat nad VFA flow in the digesta of pigs fed sucrose, fructose and glucose diets. Cuban J. Agric. Sci. 24, 79-86

Ly J., 1992. Studies of the digestibility of pigs fed dietary sucrose, fructose or glucose. Arch. Anim. Nutr. 42, 1-9

Ly J., Macias M., Figueroa V., Piloto J.L., 1994. A note on the pattern of feed intake in pigs fed Jerusalem artichoke (Helianthus tuberosus L.). J. Anim. Feed Sci. 3, 201-205

Nijkamp H.J., 1965. Same remarks aboult the determination of the heat of combustion and the carbon content of urine. In: K.L. Blaxtir (Editor). Energy metabolism. Academic Press Inc., London, pp. 147-157

Sereni J.M., 1981. Determinación en aves y cerdos de la energia metabolizable de tubérculos de topinambur. Tesis Univ. Catól. Pontif. Chile. Santiago de Chile, pp. 88

Shi X.S., Noblet J., 1993. Contribution of the hindgut to digestion of diets in growing pigs and adult sows: effect of diet composition. Livest. Prod. Sci. 34, 237-252 


\section{STRESZCZENIE}

\section{Jelitowa i calkowita strawność bulwy (Helianthus tuberosus L.) u świń}

Oznaczono strawność do końca jelita cienkiego i strawność całkowitą składników pokarmowych dawek zawierających, jako źródło energii, rafinowaną sacharozę lub bulwę, na 8 nie operowanych i 4 świniach z zespolonym jelitem cienkim $z$ odbytnicą, ważących ok. $45 \mathrm{~kg}$. Doświadczenie przeprowadzono w układzie kwadratu łacińskiego $2 \times 2$. Dawki uzupełniono poekstrakcyjną śrutą sojową dla wyrównania poziomu białka.

Strawność substancji organicznej (SO) do końca jelita cienkiego dawki zawierającej bulwę była istotnic niższa $(\mathrm{P} \leqslant 0.001)$ niż dawki $\mathrm{z}$ sacharozą $(48,5$ vs. $89,1 \%$, odpowiednio). Róźnica w całkowitej strawności SO między obydwiema dawkami była mniejsza ( $86,0 \mathrm{vs.} 95,2$, odpowiednio) i różniła się istotnie przy $P \leqslant 0,05$, co wskazuje na istotny udział jelita grubego w trawieniu bulwy.

Zawartość lotnych kwasów tłuszczowych (SCFA) przy skarmianiu dawki z sacharozą była w jelicic cienkim wiçksza, a w kale mnicjsza (117, 5 vs. $41,3 \mathrm{mmol} / 100 \mathrm{~g} \mathrm{SM})$, podczas gdy przy skarmianiu dawki z bulwą była mniejsza w jelicie cienkim niż w kale $(21,0 \mathrm{vs}, 117,8 \mathrm{mmol} / 100 \mathrm{~g} \mathrm{SM})$. Stwierdzono pewien wpływ dawki na poziom mleczanów w końcowym odcinku jelita.

Otrzymane wyniki wskazują na różnice w miejscu trawienia fruktozy, pochodzącej z badanych źródeł, i na różnice w stopniu trawienia skladników pokarmowych skarmianych dawck. 